\title{
InfoNorth
}

\section{Foraging Behaviours and Population Dynamics of Arctic Foxes}

\author{
by Gustaf Samelius
}

\section{INTRODUCTION}

$\mathrm{S}$ EASONAL AND ANNUAL fluctuations in food abundance are common in many northern environments. These fluctuations, in turn, affect both the abundance and the distribution of animals that feed on them. However, the relative importance of seasonal versus annual fluctuations in food abundance is poorly understood. Further, the extent of caching of seasonally abundant foods, such as large concentrations of nesting birds, and the implications of caching on population dynamics are unknown for most animals (Vander Wall, 1990).

Storing of foods (also termed food hoarding or food caching) is common among many birds and mammals and may be adaptive behaviour that allows animals to avoid food shortage in environments where food availability fluctuates greatly. Use of stored foods allows animals to remain in familiar areas without having to put on large amounts of body fat and is an alternative strategy to migration, torpor, hibernation, and fat storage (Smith and Reichman, 1984; Vander Wall, 1990). Food hoarding may also serve to supplement diets of growing young or to reduce time spent foraging when other behaviours are more important (Smith and Reichman, 1984; Vander Wall, 1990).

Arctic foxes (Alopex lagopus) are opportunistic predators and scavengers that rely heavily on small mammals throughout most of their range (Audet et al., 2002). However, other foods such as birds and their eggs can be critical components of arctic fox diets in some years and some parts of the Arctic (Hersteinsson and MacDonald, 1996; Bantle and Alisauskas, 1998). In fact, the ability to exploit local variation in foods and to learn new hunting skills is crucial for arctic fox survival (see Prestrud, 1992).

Arctic foxes commonly cache foods when they are abundant (Fay and Stephenson, 1989; Bantle and Alisauskas, 1998). Caching of foods appears to be especially frequent among arctic foxes living at large bird colonies (Fay and Stephenson, 1989; Samelius and Alisauskas, 2000), where foxes cache over 1000 eggs per fox during the nesting season (Samelius and Alisauskas, 2000). Large bird colonies therefore provide an ideal setting to study food caching by arctic foxes and the link between seasonally abundant foods and population dynamics.

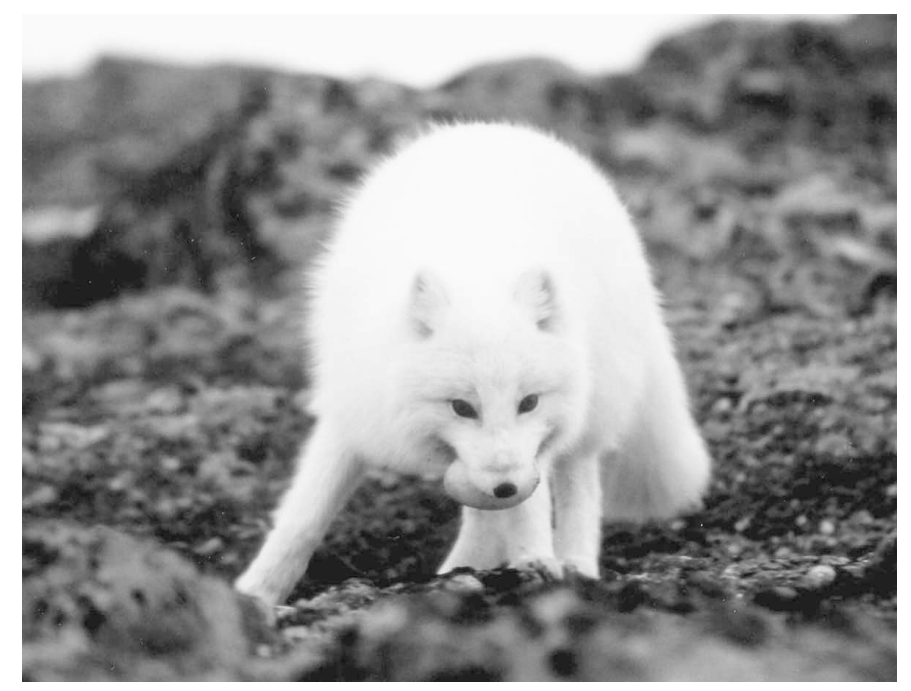

Arctic fox with a goose egg.

The main objectives of my work are to examine (1) how arctic foxes use seasonally abundant foods and (2) how seasonal and annual fluctuations in food abundance affect foraging behaviours and population dynamics of arctic foxes. I am especially interested in how arctic foxes use geese and their eggs (i.e., seasonally abundant foods) and how this varies with fluctuations in small mammal abundance (i.e., foods that fluctuate annually).

\section{STUDY AREA AND DESIGN}

My work is done at Karrak Lake $\left(67^{\circ} 14^{\prime} \mathrm{N}, 100^{\circ} 16^{\prime} \mathrm{W}\right)$ and surrounding areas in the Queen Maud Gulf Bird Sanctuary in Nunavut, Canada. Karrak Lake currently contains ca. one million nesting Ross's geese (Chen rossii) and lesser snow geese (Chen caerulescens) (Dr. R. Alisauskas, Canadian Wildlife Service, unpubl. data). My project is part of a long-term study by Dr. Alisauskas and the Canadian Wildlife Service on factors affecting the ecology of Ross's and snow geese. Fieldwork for my project was done in the spring and summers of 2000-04, and data analyses are currently under way.

I monitor population dynamics of arctic foxes in two goose nesting areas at Karrak Lake and two areas outside 


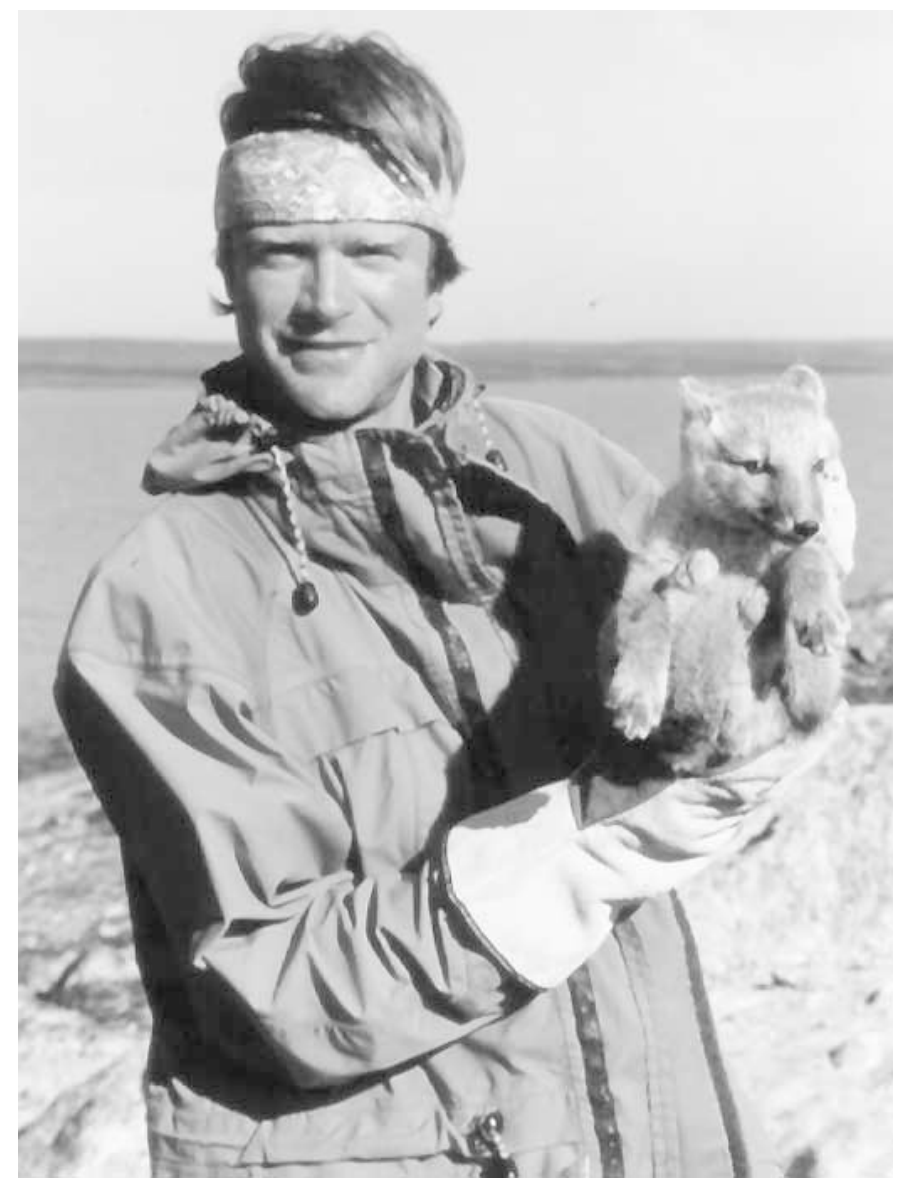

Gustaf Samelius with a two-month-old arctic fox pup.

the influence of nesting geese, whereas I monitor foraging behaviours of arctic foxes in one section of the goose colony at Karrak Lake.

\section{METHODS}

I examine foraging behaviours of arctic foxes by observing individually marked foxes with spotting scopes, following Samelius and Alisauskas (2000). Foraging success of foxes (i.e., number of foods acquired per hour) is evaluated in relation to fox characteristics (sex, size, and reproductive status), nesting distribution of geese (i.e., nesting density and stage of incubation), small mammal abundance, and fox abundance.

Avoiding cache loss to competitors is a critical component for the evolution of caching (Andersson and Krebs, 1978). I examine how nesting distribution of geese and dispersal of geese away from the colony affect cache loss by evaluating the survival rate of experimentally deployed caches (i.e., goose eggs buried in the ground) in relation to (1) nesting density of geese, (2) species composition (i.e., proportion of Ross' versus snow geese), (3) dispersal of geese away from the colony (i.e., presence versus absence of nesting geese), and (4) age of cache sites (length of time eggs were in the ground).

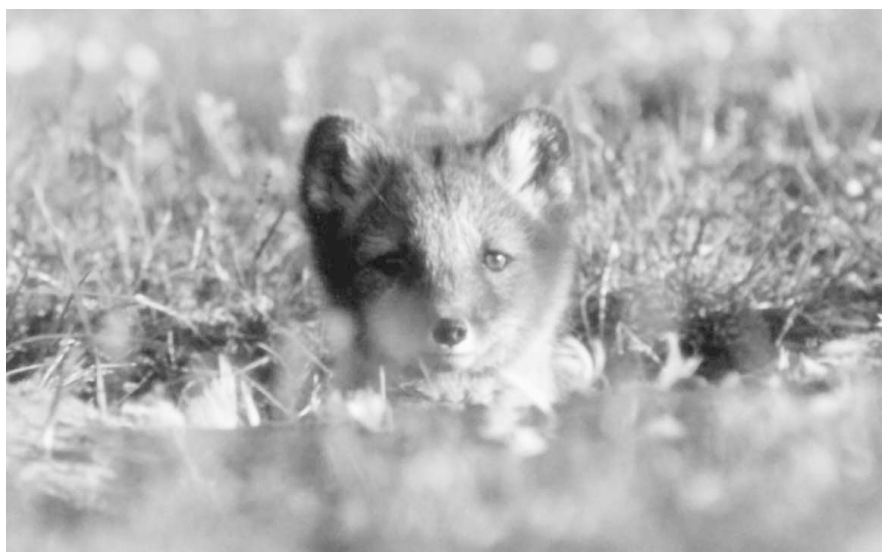

A two-month-old arctic fox pup.

I examine arctic fox diets by comparing isotope ratios ( $\delta 13 \mathrm{C}$ and $\delta 15 \mathrm{~N}$ ) of fox tissues (e.g., blood and winter fur) with those of food items collected in the field (see Kelly, 2000). Stable isotope analyses have been used widely in ecological studies and are based on the fact that stable isotope signatures in animal tissues reflect those of their foods (Hobson, 1999; Kelly, 2000). Fur is metabolically inactive, whereas blood is metabolized continuously (Hobson, 1999), so by examining spring blood and winter fur I obtain information on both spring and fall diets. Geese are not present at Karrak Lake in either spring or fall, so goose signatures in this study represent foods cached in summer.

I monitor population dynamics of arctic foxes (e.g., fox abundance, density of breeding foxes, and litter size) through line-transect surveys, mark-recapture studies, and den inventories. Dens were located by systematic surveys of all study areas in the spring and summer of 2000.

\section{PRELIMINARY RESULTS}

Goose eggs (from both nests and existing caches) made up $91 \%$ of all foods taken by arctic foxes during goosenesting at Karrak Lake. Foxes cached $96 \%$ of these eggs (i.e., most eggs from existing caches were moved to new locations), whereas other foods (i.e., small mammals, geese, and passerine eggs) were either consumed immediately or brought back to den sites. Arctic foxes appeared to take similar numbers of eggs from goose nests and existing caches regardless of their sex, size, and reproductive status. Instead, the main factors affecting the rate at which foxes took eggs from goose nests appeared to be nesting density and acquisition of eggs from existing caches, suggesting that moving of eggs from existing caches occurred at a cost to acquisition of eggs from goose nests.

Age of cache sites and dispersal by geese away from the colony after hatch (when ca. 1 million geese and their offspring leave the colony in about 10 days) affected loss of experimental caches. These results suggest that both food abundance and strategies to prevent ageing of cache 
sites (e.g., cache site selection and moving of caches in poor condition) were important in affecting the arrangement of caches at our study site.

Cached eggs constituted $30 \%$ to $40 \%$ of the arctic foxes' diet in autumn and $0 \%$ to $30 \%$ in spring. The use of cached goslings appeared to be similar to that of cached eggs, but requires further investigation, as the isotopic signature of goslings is similar to that of lemmings. The use of cached eggs appeared to be negatively correlated to small mammal abundance, with more eggs used in years when small mammals were scarce.

The abundance of arctic foxes was predominantly affected by abundance of geese (i.e., foxes were more than twice as abundant in the goose colony than outside the colony), whereas the density of breeding foxes and litter size were predominantly affected by small mammal abundance.

\section{SIGNIFICANCE}

This study will provide information on how seasonal and annual fluctuations in food abundance influence use of stored foods and population dynamics of arctic foxes. This may be important information, as large-scale climatic changes in northern environments (IPCC, 2001) may alter the distribution and abundance of Arctic organisms (Root et al., 2003). Knowing how seasonal and annual variations in food abundance affect Arctic fauna is therefore important to understanding how climatic changes may influence the dynamics of Arctic environments. My work on food caching is also of general interest because the extent of caching and its implications on population dynamics are unknown for most animals (Vander Wall, 1990). My work with stable isotopes will, for example, provide the first estimate on use of stored foods by a carnivore species.

This study will also provide information on predatorprey interactions, which can be used for management and conservation of both arctic foxes and Arctic-nesting birds. Proper management of natural resources is important to people in many northern communities, where hunting and trapping are integral parts of the culture and economy (Usher, 1971; Bromley, 1996).

Please visit www.usask.ca/biology/fox for more information on my project.

\section{ACKNOWLEDGEMENTS}

I am very honoured to be the recipient of the Jennifer Robinson Memorial Scholarship for 2004. I am also very grateful for support from the California Department of Fish and Game, the Canadian Wildlife Service, the Delta Waterfowl Foundation, Ducks Unlimited, the Polar Continental Shelf Project, the Sweden-America Foundation, and the University of Saskatchewan. Many thanks to my advisor Dr. R. Alisauskas and my co-advisor Dr. S. Larivière for their help and support, and to J. Aitaok, J. Bantle, C. Bergman, R. de Carle, C. Hendrickson, W. Kurz, A. Lusignan, K. Phipps, J. Pitt,
D. Stern, and N. Wiebe for excellent assistance and company in the field. Special thanks to J. Aitaok, B. Eyegetok, and D. Stern for help and hospitality in Cambridge Bay.

\section{REFERENCES}

ANDERSSON, M., and KREBS, J. 1978. On the evolution of hoarding behaviour. Animal Behaviour 26:707-711.

AUDET, A.M., ROBBINS, C.B., and LARIVIÈRE, S. 2002.Alopex lagopus. Mammalian Species 713:1-10.

BANTLE, J.L., and ALISAUSKAS, R.T. 1998. Spatial and temporal patterns in arctic fox diets at a large goose colony. Arctic 51(3):231-236.

BROMLEY, R.G. 1996. Characteristics and management implications of the spring waterfowl hunt in the western Canadian Arctic, Northwest Territories. Arctic 49(1):70-85.

FAY, F.H., and STEPHENSON, R.O. 1989. Annual, seasonal, and habitat-related variation in feeding habits of the arctic fox (Alopex lagopus) on St. Lawrence Island, Bering Sea. Canadian Journal of Zoology 67:1986-1994.

HERSTEINSSON, P., and MACDONALD, D.W. 1996. Diet of arctic fox (Alopex lagopus) in Iceland. Journal of Zoology (London) 240:457-474.

HOBSON, K.A. 1999. Tracing origins and migration of wildlife using stable isotopes: A review. Oecologia 120:314-326.

IPCC (INTERGOVERNMENTAL PANEL ON CLIMATE CHANGE). 2001. Climate change 2001: Impacts, adaptation, and vulnerability. Contribution of Working Group II to the IPCC Third Assessment Report. Edited by Houghton, J.T., Ding, Y., Griggs, D.J., Noguer, M., van der Linden, P.J., and Xiaosu, D. Cambridge: Cambridge University Press. 944 p.

KELLY, J.F. 2000. Stable isotopes of carbon and nitrogen in the study of avian and mammalian trophic ecology. Canadian Journal of Zoology 78:1-27.

PRESTRUD, P. 1992. Food habits and observations of the hunting behaviour of arctic foxes, Alopex lagopus, in Svalbard. Canadian Field-Naturalist 106:225-236.

ROOT, T.L., PRICE, J.T., HALL, K.R., SCHNEIDER, S.H., ROSENZWEIG, C., and POUNDS, J.A. 2003. Fingerprints of global warming on wild animals and plants. Nature 421:57-60.

SAMELIUS, G., and ALISAUSKAS, R.T. 2000. Foraging patterns of arctic foxes at a large Arctic goose colony. Arctic 53(3): $279-288$.

SMITH, C.C., and REICHMAN, O.J. 1984. The evolution of food caching by birds and mammals. Annual Review of Ecology and Systematics 15:329-351.

USHER, P.J. 1971. The Bankslanders: Economy and ecology of a frontier trapping community. Volume 2: Economy and ecology. Ottawa: Department of Indian Affairs and Northern Development.

VANDER WALL, S.B. 1990. Food hoarding in animals. Chicago: University of Chicago Press.

Gustaf Samelius is a doctoral candidate in the Department of Biology, University of Saskatchewan in Saskatoon. He is the winner of the Jennifer Robinson Scholarship for 2004. 